\title{
Contribuição de Francisco de Vitoria ao Direito Internacional Público no de "Indis Recenter Inventis, Relectio Prior".
}

\author{
Oris de Oliveira
}

\section{Introdução.}

Fenômeno global, o subdesenvolvimento tem implicações as mais diversas, inclusive nos setores da cultura jurídica. Neste e em outros campos cria-se um círculo vicioso, que se revela na falta de mercado consumidor, na falta de demanda e de oferta de obras de primeira mão, fazendo com que se tenha uma cultura de mediação.

Sofremos no Brasil a carência de edições críticas fundamentais do pensamento humano. Faltam-nos até traduções fiéis que nos coloquem em contato direto com os "clássicos" em todos os ramos do saber.

Vejamos um caso concreto. Não há estudioso, nem mesmo estudante, que desconheça ter sido Francisco dE VITória um marco importante na evolução do Direito Internacional Público, graças, sobretudo, à obra De Indis recenter inventis, relectio prior.

Quantos estudiosos no Brasil tiveram possibilidade de ler esse livro? Pouquíssimos, certamente, mas continuar-se-á ouvir e repetir através de anos a mesma afirmação.

Tentando romper com as cadeias deste círculo, pretendemos, através de modesta colaboração, oferecer, dentro em

*. Trabalho apresentado na cadeira de Direito Internacional Público do Curso de Especialização da Faculdade de Direito da Universidade de São Paulo, em fevereiro de 1969. 
pouco, uma tradução desta obra do Mestre de Salamanca. $O$ trabalho que ora apresentamos é apenas esbôço de parte da introdução geral.

\section{Itinerário ideológico da Obra.}

I. Questão de consciência: atualidade do problema. II. $O$ impasse dos jurisconsultos. III. Reformulação da concepção jurídica do problema: a. no plano filosófico-jurídico: jusnaturalismo. b. no plano do Direito Positivo: "Jus inter Gentes".

I. Questão de consciência: - atualidade do problema.

Ao voltar de Paris, onde estudara e lecionara, para sua terra natal, Francisco de Vitória, primeiramente em Valladolid (1523-26) e mais tarde em Salamanca (1526) deparou a consciência cristã espanhola em crise face a um problema objeto de acirradas, ou melhor, acirradíssimas controvérsias.

LEwis HaNcke focaliza bem o problema nestes termos: - "Que direitos políticos e econômicos decorriam para a Espanha de sua nova Soberania? Os índios eram dotados de razão, e quais seus direitos? Como instruí-los na nova religião? Em que casos podem ser coagidos a trabalhar para os Espanhois? Podia-se declarar guerra justa contra êles?"1

Anos antes (1510) el Rei escrevera ao Prior dos Dominicanos de Salamanca pedindo que seus súditos moderassem suas paixôes sôbre uma questão "nefasta e escandalosa", que recolhessem os sermões feitos, que ninguém imprimisse nada a respeito sem ordem real.

De um lado os missionários defendendo ferrenhamente os indios contra os diversos abusos, usando, todavia, um fraco aparelhamento técnico científico, ou melhor, "jurí-

1. LEWIS HANCKE, Colonisation et conscience chrétienne au XVI siècle (p. IV). 
dịco teológico". Era o pregador utilizando a oratória, tentando descrever com quadros negros a crueldade do conquistador, tentando difundir uma imagem do índio sem civilização, mas bom e inofensivo, tentando, enfim, obter dos soberanos ou dos papas pronunciamentos favoráveis, quando mais não fosse sobre a condição de homens dos bárbaros.

Foi incontestàvelmente uma vitória quando a Sublimis Deus de Paulo iII (1537) declarou verdade de fé que os índios eram verdadeiros homens, capazes de salvação e de receber os sacramentos.

Do outro lado o conquistador, escondendo a cobiça pelo ouro, alegando trabalhar para a glória da Espanha e conseqüentemente para a glória da Igreja, aquí na América utilizando a fôrça, no continente contando, não com a eloqüência sentimental, mas com a forte cobertura ideológica dos "jurisconsultos" teocráticos.

Francisco de VITória percebeu então que seu silêncio poderia ser comprometedor, a problemática tornou-se para êle "uma questão de consciência".

Pressionado, certamente, por irmãos de hábitos, missionários que voltavam à Salamanca, ViTóRIA se viu na obrigação de submeter a matéria a aprofundado exame.

\section{O impasse dos jurisconsultos.}

Seguindo uma velha tradição, que ainda hoje se perpetua, o teólogo VıTóRIa parecia não nutrir muita simpatia pelos jurisconsultos.

E a mesma ironia hodierna dos filósofos juristas contra os práticos do direito e dêstes contra aquêles, que vivem no mundo da lua.....

Mais de uma vez o Mestre de Salamanca fêz questão de colocar os canonistas no devido lugar.

Embora reconhecesse serem os jurisconsultos os únicos a tratar da matéria, o assunto não era de sua alçada. 
Com certa benignidade, que a ninguém engana, concedia que também pudessem estudar o assunto. ${ }^{2}$

Em certa passagem não deixa de fazer forte crítica a seu irmão de hábito Antonino de Florença, porque êste costumava seguir demais as pegadas dos canonistas ..... ${ }^{3}$

Seria, todavia, diminuir a importância do assunto pensar que a hostilidade de VrróRIa pelos jurisconsultos fôsse uma questão puramente pessoal.

Na verdade percebera com clarividência que os canonistas tinham levado a problemática para um impasse.

Os juristas de então, primeiramente porque profundamente marcados pelo teocratismo e principalmente porque cientistas de um direito positivo, não submetiam o assunto a uma "crítica radical".

Alexandre VI outorgando-se direitos teocráticos não dividira o mundo entre espanhóis e portuguêses?

Estes textos de bulas deviam ser aceitos, comentados na esfera da jurisprudência.

Sua "legalidade" era indiscutível. Resultado: a solucão, que se impunha dentro desta perspectiva, era o enquadramento dos povos recém-descobertos dentro de um esquema de cristandade medieval teocrática.

Mandatários dos Sumos Pontifíces, os espanhóis podiam ocupar as terras "papais" do novo continente, podiam tratar seus possuidores como "infiéis", tê-los como prisioneiros de guerra, podiam, conseqüentemente, e isto é que interessava, submetê-los à escravidão, pô-los a serviço da procura do ouro.

2. "Secundo dico, quod haec determinatio non spectat ad jurisconsultos vel saltem non ad solos illos. Quia cum illi barbari, ut statin dicam, non essent subjecti jure humano, res illorum non sunt examinandae per leges humanas, sed divinas, quarum juristae non sunt satis periti ut per se possint hujusmodo quaestiones definirenenec satis scio an unquam ad dispataputationem hujus quaestionis vocati fuerint theologi tio ven digni, qui audiri de tanta re possint". De Indis, relectio prior, p. 649 .

3. DE INDIS, p. 684 . 
Nesta hora nada mais perigoso do que a preguiça intelectual ou a deformação de visualização científica restrita porque uma ou ambas podem se julgar defensoras de verdades tradicionais e imutáveis.

Não tinham os juristas capacidade para perceber que o pensamento cristão encontrava-se diante de situação completamente nova.

Sem levar em conta essas considerações um leitor menos avisado pode não entender porque Francisco de ViTória dedica longa parte de sua obra na refutação dos títulos ilegitimos de dominio dos espanhois sobre os índios e suas terras.

Uma a uma são analisadas as justificativas ideológicas da conquista e refutadas dentro do mais estrito rigor escolástico.

Vejamos ràpidamente as soluções apontadas pelos defensores dos conquistadores -

$\left.1^{\circ}\right)$ imperador é senhor de todo o orbe e conseqüentemente também dos índios.

$\left.2 .^{\circ}\right)$ Sendo o Papa senhor de todo o orbe, conferiu aos reis de Espanha domínio sôbre os bárbaros e suas terras. Nesta afirmação estava condensada tôda teocracia medieval, bem definida por ViróRIa nos seguintes têrmos: "Potestas imperatoris et omnium aliorum principes est subdelegata repectu Papae et quod est derivata a Deo mediante Papa, et quod tota illorum potestas dependet a Papa".4

4. DE INDIS, p. 676.

("Dicunt auctores hujus sententiae: primo quod papa libere potuit constituere principes barbarorum reges Hispaniae, tanquam supremus dominus temporalis. Secundo dicunt quod, hoc non posset, saltem si barbari nolunt recognecere dominium temporale Papa in eos, hac ratione potest eis inferre bellum et imponere principes. Utrumque autem factum est, nam Summus Pontifex concessit illas provincias regibus Hispaniae, secundo etiam barbaris propositum fuit et significatum quod Papa est vicarius Dei et habet vices ejus in terris, et ideo quod recognacant eum superiorem, quod si illi recusaverint, am iusto titulo est eis bellum inferendum et occupatae provinciae illorum, etc" (Ibidem, p. 677 e 678). 
$\left.3 .^{\circ}\right)$ Direito de descobrimento: - o que fôr deserto é de quem ocupa primeiro.

$\left.4 .^{\circ}\right)$ Relutância dos índios em aceitar a fé cristã.

$\left.5 .^{\circ}\right)$ Os pecados dos índios contra a natureza.

$\left.6 .^{\circ}\right)$ Eleição voluntária. Os índios escolheram os espanhóis como seus senhores e reis.

7. $\left.{ }^{\circ}\right)$ Por especial dom de Deus. Os bárbaros pelos seus pecados mereceram uma condenação divina: - ser entregues aos espanhóis (sic), que passariam a exercer, à moda judaica, a função de "povo de Deus".

Se exceptuarmos os $3 .^{\circ}$ e $6 .^{\circ}$ títulos acima apontados, percebe-se que tôda a fundamentação ideológica se fazia dentro de uma perspectiva de teocratismo papal: - fundamentação bíblica, pecado, infidelidade, providencialismo divino em favor dos espanhóes.

Homem profundamente conhecedor da escolástica, ViTóRIa tinha condições de enfrentar seus opositores no próprio campo de combate. Refutou, pois, todos os títulos ilegítimos, utilizando-se das mesmas armas dos opositores.

Dizer que o Imperador é "Dominus" de tôda a terra, e conseqüentemente dos índios, é opinião destituída de qualquer fundamento: - "haec opinio est sine aliquo fundamento". Em seu favor não pode invocar nenhum direito divino, natural ou humano. Mesmo que Cristo fosse senhor de todo o Universo (o que Vitória coloca em dúvida) nem por isso o Imperador poderia invocar êste domínio em seu favor, por tratar-se de suposição gratuita, sem base nas escrituras e na história.

Mais difícil foi refutar o segundo título porque nele se fazia sentir o pêso da tradição teocrática papal: - "secudus titulus qui praetenditur et quidem vehementer asseritur"5.

Primeiramente, com certo desdém, VITóRIA minimiza a fôrça da argumentação por tratar-se de opinião de juris-

5. DE INDIS, p. 676. 
consultos (ib), com cujas afirmações não devemos nos preocupar $^{6}$.

Em proposições categóricas, fortemente ilustradas com citações bíblicas e com "auctoritates" escolásticas, o Mestre de Salamanca assim encadeia seu pensamento:-

Primeiro: - O Papa não é senhor civil ou temporal de todo o orbe, falando-se, evidentemente, no sentido próprio de domínio ou poder civil.

Segundo: - Mesmo que o Papa tivesse o poder secular não o poderia transmitir aos príncipes seculares.

Terceiro: - O Papa tem poder temporal na medida exata em que ordenada ao espiritual, isto é, o quanto exato para a administração das coisas espirituais.

Quarto: - O Papa não tem nenhum poder sôbre êstes bárbaros, nem tampouco sôbre outros infiéis.

Conseqüentemente (sequitur corolarium) : - mesmo que os índios não queiram reconhecer qualquer domínio do Papa, este não pode infringir-lhes guerra ou apossar-se de seus bens. ${ }^{7}$

Foi fácil para Virória refutar o título do domínio dos espanhóis no descobrimento, simplesmente porque não era verdade que ninguém ocupasse os territórios dos índios. Êstes poderiam ter uma estruturação societária diferente da dos ibéricos mas a tinham.

Fôsse o raciocínio válido também os índios poderiam ter descoberto os espanhóis na Península Ibérica e desalojá-los de sua pátria...

6. “Nec auctoritas canonistarum in contrarium multum debet movere, quia (ut supra dictum est) haec tratanda sunt jure divino et plures et maiores in contrarium tenent, inter quos etiam est Ioannes Andreas, nec habent pro se aliquem textum, nec etiam gravis auctoritas archiepiscopi Florentini hoc loco recipienda est, secutus est enim Augustinum Anchonitanum, sicut solet sequi canonistas".

7. De INDIs, p. 678-682. 
Quanto à obrigação de os bárbaros receberem a fé cristã, havia, segundo VITóRIA, todo um sofisma na argumentação.

Embora na sua opinião fôssem os índios sujeitos aos critérios gerais de aceitação da fé, quando proposta com milagres, e com o bom exemplo, senão a recebessem, aos espanhóis não cabia o direito de perseguir pela guerra e espoliar bens.

Os conquistadores outorgavam-se, também, a função de punidores dos indios por causa de seus pecados conira o direito natural. Contra tal prerrogativa a conclusão do Mestre é taxativa: - os príncipes cristãos mesmo com autorização do Papa, não podem obrigar os bárbaros a afastar-se dos pecados contra a natureza, nem puní-los por estes pecados.

Embora VITóRIA evidentemente não admitisse a relatividade cultural do juízo moral sôbre certos pecados contra a natureza, faz notar, todavia, que às vêzes, é mais fácil provar verdades religiosas reveladas do que convencer que certos atos são contra lei natural. ${ }^{8}$

Não foi difícil desmascarar a falta de fundamento dos títulos sexto e sétimo ilegítimos.

Só um ingênuo poderia crer que os índios escolheram livremente, sem medo e sem coação, os conquistadores como seus senhores e reis. $\mathrm{E}$, ainda mais: o povo não pode sem causa razoável escolher novos senhores em detrimento dos antigos; os príncipes, por seu lado, não podiam aceitar a sujeição dos espanhóis sem assentimento do povo. ${ }^{9}$

Dizer que os bárbaros mereceram a condenação de Deus a tal ponto de serem entregues nas mãos dos espanhóis para estes exercerem a função de povo de Deus, é "profecia" sem fundamento.

8. "Profecto maiores prabationes habemus ad probandum legem Christi esse a Deo et esse veram quam ad probandum quod fornicatio est mala, vel quaerenda alia etiam lege prohibita". De Indis, p. 701.

9. Ibidem, p. 702 . 
Perdoe-nos o leitor a enumeração dos títulos ilegítimos e a refutação. Reconhecemos que poucas cousa se colhe aqui sôbre direito internacional público. Talvez mereça especial menção a afirmação final de VITóRIA: - "hispani, cum primum navigaveruntad terras barbarorum nullun jus secun afferebant occupandi provincias illorum"10, afirmação cuja densidade poderemos apreciar mais adiante.

Queríamos nós que o leitor sentisse a colocação do problema antes da abordagem por VitónIA e o impasse em que se encontravam as soluções propostas.

Um leitor menos avisado, que desconhecesse as implicações concretas, poderia pensar tratar-se de disputas entre doutos, poderia mesmo perguntar onde se encontrava o impasse.

Este consistia no fato da ideologia dos jurisconsultos teocráticos, dos Sepulvedas, justificar, não digo todas, e cada uma das crueldades e arbitrariedade cometidas pelos conquistadores, mas justificar globalmente o modo de se comportarem os espanhóis: - desapropriação dos bens dos índios, submissão à escravidão, guerras, crueldades, tudo isso encoberto pela nobre missão de delegados do papa, transportando, enfim, para o continente americano toda uma ética medieval de comportamento do cristão em relação ao infiel, ao muçulmano e ao hereje.

Veio, portanto, em boa hora a pressão dos missionários sôbre Francisco de VITória, obrigando a engajar-se na disputa porque a evangelização dos bárbaros estava irremediàvelmente comprometida.

\section{Reformulação jurídica de VITóRIA.}

VITóRIA era um teólogo que não morria de amores pelos jurisconsultos e canonistas, nós já o sabemos. Percebendo que havia necessidade de colocar a problemática em outras perspectivas, elevou-a a um plano filosófico (no seu modo de conceituar, teológico).

10. Ibidem, p. 684 . 
Não é todavia pelo gosto do paradoxo que afirmamos que nem por isso deixou de julgar a questão também sob prisma jurídico.

Desde o início da obra a afirmação é categórica e explícita: - "Circa quos (barbaros) praesens disputatio habetit tres partes: - In prima tractabitur quo jure venerint barbari in detionem hispaniorum"11.

Apenas esta primeira parte foi objeto das relectiones prior et posterior.

Cremos nós, que a contribuição de VITória consistiu em colocar a problemática nas perspectivas de filosofia juridica e de direito internacional público.

Uma observação preliminar, todavia é importante: a obra não é dividida materialmente de modo a se distinguir a parte em que o problema é focalizado no âmbito da filosofia jurídica ou do Jus Inter Gentes. Estes aspectos se descobrem nos meandros de seus pensamento.

\section{a. Perspectiva - Jus-filosófica.}

Seria fora de propósito estendermo-nos aqui sôbre a filosofia jurídica do De Indis. A matéria foi objeto do trabalho final para aprovação no Curso de Pós-Graduação da Cadeira de Filosofia e Sociologia Jurídicas e que será publicado em breve na Revista da Faculdade de Direito.

Seja-nos, todavia, permitido resumir em poucas linhas alguns dados fundamentais que se concatenam com o assunto dêste trabalho.

Deixando de lado o enquadramento escolástico e consciência do autor de estar fazendo teologia, em que se revelou a perspectiva filosófica do $D e$ Indis?

Primeiro submetendo a matéria a uma crítica radical: houve então uma reversão de perspectiva, submetendo a juizo filosófico a justiça global da conquista. Tudo o que era certeza foi submetido a novo exame.

11. De Indies, p. 642. 
Discordamos neste particular completamente de $\mathbf{T}$. Urdanoz quando escreve: - "VIróRIA, pues, no parece abrigar dudas, en este su punto de partida, sobre la justicia global de la conquista y ocupation de las Indias sobre los fundamentos teóricos que se daban...".

(T. URdANoz, opus citatum, Introduction a la Relecion primera, p. 516).

Parece haver uma confusão na mente de UdANoz entre a situação de fato e as justificativas ideológicas. A ocupação das Índias era uma situação irreversível, de que o Mestre de Salamanca tinha plena consciência inclusive de que as elocubrações filosóficas não a iam alterar. ${ }^{12}$

Pôs, todavia, o problema em têrmos amplos, podendo em rigor concluir pela negativa de uma justificação. Situada a problemática em plano superior, apelando para os mesmos princípios, de um lado justificou, não o poder de os espanhóis dominarem os índios mas de conviverem (título societatis et communicationis) com êstes, de outro, o direito de os bárbaros não serem despojados de sua soberania.

Houve, conseqüentemente, um juízo global e crítico-filosófico.

Sua filosofia jurídica evidenciou-se sobretudo dando, no modo de ver, a razão última do Jus Inter Gentes, fundamentando-o no jusnaturalismo.

URDANoz, conhecedor do pensamento vitoriano e de seu enquadramento na escolástica, resume bem: - "Para sua demonstração Vitória estabelece o fundamento último do direito: - consiste êsse na dignidade da pessoa humana como ser racional. $O$ homem constitue-se em pessoa moral e sujeito capaz de direitos e deveres por sua racionalidade, porque é pelo uso de sua faculdade racional e consequente liberdade, que tem domínio de seus atos, pode escolher livremente seus destinos e usar as cousas e seres inferiores para seus próprios fins e em seu benefício. A faculdade ra-

12. Cf. DE INDIS, p. 725-726. 
cional é, pois, a raiz fundamental formal que outorga ao homem ser capaz de domínio e de direitos".13

Donde a preocupação constante de VITóRIa de vincular o jus Gentium ao direito natural, donde sua intransigência em não permitir que razões, supostamente de ordem da fé, viessem infirmar o direito natural dos indios: - "fides non tollit nec jus naturale nec humanum" 14

b. Plano do Direito Positivo: - Jus inter Gentes.

I) Considerações metodológicas. II) Caracteres do Jus Gentium. 1. Jus inter Gentes, internacional. 2. Sujeitos dêste direito. 3. Direito positivo. 4. Legítima defesa dêste direito: guerra. III) Elementos positivos dêste direito. 1. Igualdade jurídica dos povos.

1. Direito de convivência e de intercomunicação. 2. Livre utilização do mar, portos e rios. 3. Direito de cidadania $e$ de trabalho para o estrangeiro. 4. Direito de defesa dos inocentes. 5. Direito de integração dentro da soberania. 6. Direito de colonização.

I. Considerações metodológicas.

O desmembramento de um ramo de ciência comporta uma longa gestação, não poucas vêzes, à final, com um doloroso parto. $\mathrm{O}$ historiador das ciências humanas sabe disso e só estranharia se houvesse o aparecimento inesperado de uma ciência sem um longo período de amadurecimento.

Esste fenômeno vamos encontrar na ciência do direito internacional público.

Embora iniciador deste ramo autônomo do saber não esperemos de ViTóRIA mais do que êle poderia nos dar. Não esperemos dele considerações epistemológicas sobre a matéria. O que vamos deparar é o paradoxal. O Mestre de Salamanca pensava estar exercendo uma teológia, e não tinha consciência de estar criando uma ciência autônoma.

13. Op. citatum, p. 521.

14. DE INDIS, p. 656. 
Nós é que não temos o direito de confundir a consciência do autor sôbre sua obra com a real objetivação da matéria. Assim como Mr. Jourdain fazia prosa sem sabê-lo, há os que penetram nos campos das diversas ciências ignorando, chegando, às vêzes ao paradoxo de negar-lhe o objeto específico.

Francisco de Vitória falava tanto do Jus Gentium em suas diversas obras que poderia nos ter legado uma cujo objeto fosse justamente este tema, assim como escrevera obras de Potestate Civili, De Potestate Ecclesiae, etc.

Infelizmente, todavia, isto não aconteceu. O De Indis é apenas uma monografia circunscrita dentro da problemática das relações entre índios e espanhóis. Conseqüentemente os elementos de direito internacional público que nela poderemos encontrar estão delimitados à temática da obra. Para sintetizar somos obrigados a colher aqui e acolá elementos concordantes mas esparsos, enquadrados em contextos diversos, e até mesmo em outras obras.

\section{Caracteres do Jus Gentium.}

Longa é a história do Jus Gentium. Seria completamente fora do propósito relembrar, ainda que sucintamente, a evolução por que passou. Autores há que o fizerem perfeita e exaustivamente. (cf. bibliografia). Há, todavia, unanimidade entre os historiadores em afirmar que a partir de ViTóRIA o Jus Gentium passou por uma transformação em sua conceituação.

Poucos nos interessa o juízo que se faça do fenômeno, considerando um "desvio" de uma rota certa (como pensa URDANoz) ou uma transformação para melhor.

Para compreender em um contexto mais amplo o pensamento do Mestre de Salamanca a respeito sentímo-nos na obrigação de sintetizar em algumas linhas elementos esparsos de sua cosmovisão ideológica. Mundividência ideológica, não nos esqueçamos, cujas fontes "históricas" eram a Biblia e as tradições patrística e escolástica. 
VITória não considera o homem apenas como ser isolado. Êle se integra em vários agrupamentos sociais, todos regulados por normas jurídicas. Dentro da sociedade familiar há uma relação de direito entre marido e mulher, esta, diga-se de passagem subordinada àquele, entre pais e filhos.

Seguindo as pegadas de velha tradição VITóRIA crê ter havido um comunismo primitivo que fazia de todos os homens um só grupo social em que se adotava o uso comum dos bens ${ }^{15}$.

Contingências históricas, todavia, obrigaram os homens a se dividirem em grupos de nações para ocupar tôda a terra. Por ordem de Noé (sic), ou mais provàvelmente "ex consensu mutuo gentium" diversos grupos familiares ocuparam provincias diversas, criando também "ex consensu communi", príncipes que os governassem. Assim começaram a existir diversas repúblicas "perfeitas"16 no mundo, que se perpetuaram até nós ${ }^{17}$

A gênese, portanto, das nações ou principados está vinculada ao "consenso comum dos povos",18 expressão esta que significa na linguagem vitoriana ser a própria origem dos povos fruto do Direito das Gentes.

A partir de então essas comunidades passam a ter vida autônoma, ou melhor, em têrmos nossos, a ter soberania, com direitos próprios e inalienáveis porque, segundo Vitória, decorrentes do direito natural. Os povos podem integrar-se em comunidades maiores. Não há dúvida, por exemplo, que VrTória achava normal a existência de uma cristandade como comunidade de povos soberanos cristãos.

15. De Indis, p. 706 .

16. "Est (ergo) perfecta respublica aut communitas, quae est per se totum, id est, quae non est alterius reipublicae pars, sed quae habet proprias leges, proprium consilium et proprios magistratus" (De Indis, relectio posterior, p. 822).

17. De Indis, p. 672.

18. De Indis, relectio posterior, p. 822 . 
Estes deveriam subordinar seus interêsses particulares ao da cristandade, evitando, por exemplo, rupturas internas que pudessem beneficiar o inimigo comum ${ }^{18}$. Até em guerras entre si êstes povos cristãos poderiam estabelecer normas mais benignas de comportamento como por exemplo no tratamento dos prisioneiros.

Vitória vai, porém, mais adiante e seu raciocínio entra na esfera do direito internacional público.

Apesar das diversificações em povos soberanos a humanidade no seu conjunto não deixa de ser uma "respublica", composta não só de homens isoladamente considerados, mas de povos distintos.

Esta "respublica" faz as leis justas e equânimes que convém a todos os povos. Estas leis constituem o "Jus Gentium".

"Habet enin totus orbis, qui aliquo modo est una respublica, potestatem ferendi leges aequas et convenientes omnibus, quales sunt im jure gentium. (Ex quo patet quod moraliter peccant violantes jura gentium sive pace sive in bello. In rebus tamen gravioribus, ut est de in columitate legatorum) neque licet uni regno neque teneri jure gentium: est enim latum totius orbis auctotitate" 20

Urdanoz, com rara felicidade, notou a inovação de ViTóRIA sôbre o "Jus gentium": - "O Mestre começa esta exposição com uma inovação genial enunciando a definição de direito internacional como distinto da esfera do direito privado, introduzindo uma simples mudança de palavra na fórmula que o jurista romano definia o jus gentium: - "quod naturalis ratio inter omnes homines constiutit vocatur jus gentium". Sentença que VrróRIA adapta mediante a substituição de "homines" por "gentes" para significar o direito internacional público: - "quo naturalis ratio inter gentes constituit ${ }^{21}$.

vT. De Indis, p. 840 .

20. De Potestate Civili, p. 191.

21. T. URDANOZ, op. cit., p. 568. 
Trata-se, pois, no sentido restrito da palavra, de um direito inter-nacional.

Em resumo, o Jus Gentium passa a ser conceituado como conjunto de leis equânimes que regulam convenientemente a relação entre os diversos povos, não sendo permitido a um povo individualmente furtar-se ao seu cumprimento.

\section{Sujeito do Jus Gentium.}

Não há dúvida que para ViTóRIA os povos, na medida em que se constituem como comunidades independentes, perfeitas e soberanas, são as pessoas do jus inter gentes.

Nas suas relações os povos devem obedecer a êste direito, cuja violação pode dar origem à legitima defesa pela guerra.

Não será difícil demonstrar que é êste exatamente o pensamento de ViTóRIa no $D e$ Indis em duas partes fundamentais da obra: - na primeira quando justifica o direito de domínio dos índios sôbre as terras que possuiam e na segunda quando examina os títulos que legitimam a convivência dos espanhóis na América.

O domínio, o direito de propriedade das terras, que é defendido, não é só o de cada um dos indígenas mas do povo como nação soberana.

Quanto ao direito de convivência o Mestre deixou ainda mais claro tratar-se não só de direito dos indivíduos mas do povo espanhol.

\section{Caráter positivo do Jus gentium.}

Há um texto do De Potestate Civili (1528) que condensa, com rara felicidade, tudo o que há de esparso no $D e$ Indis sôbre o caráter positivo do Jus Gentium.

"Jus gentium non solun habet vim ex pacto et condicto inter homines, sed etiam habet vim legis. Habet enim totus orbis, qui aliquo modo est una respublica, protestatem fe- 
rendi leges aequas et convenientes omnibus, quales sunt in jure gentium"22.

Essa fôrça de lei (vis legis) é o poder coercitivo sem o qual haveria apenas recomendação de ordem moral.

A formação escolástica e a filiação doutrinária a Tomás DE AQuino não permitiriam ao Mestre de Salamanca deixar de abordar o seguinte problema: — quem é o legislador dêsse direito inter gentes?

Em têrmos escolásticos: - qual a causa eficiente das normas positivas dêsse direito?

O texto De Potestate Civili acima citado atribue esta função a todo o orbe, na medida em que é uma república. VITória nem de longe pensa em alguma entidade internacional, como a temos hoje. Dizer, pois, que todo o orbe é uma república, que tem o poder de legislar, e que êste poder se concretizar no direito das gentes, é muito vago.

Há um segundo texto, que distingue dois modos de elaboração das leis: - o primeiro é o da "conscientização" progressiva, o segundo pelo "consensus maioris partis totius orbis".

O processo de conscientização leva os povos a aceitarem como obrigação certos modos de comportamentos por exigência da natureza humana. Na medida em que forem considerados como naturais, os povos não podem recusar certas obrigações em seu mútuo relacionamento sem negar a si mesmos como homens: - "multa videntur procedere ex jure gentium, quod quia derivantur sufficienter ex jure naturali, manifestam vim habet ad dandum jus et obligandum ${ }^{23}$.

Também o "consenso da maioria dos povos" é legiferante, mesmo que haja discordância de uma minoria: "Et dato quod non semper derivetur ex jure naturali, satis videtur esse consensus maioris partis totius orbis, maxime pro bono communi omnium. Si enim post prima tempora

22. De Potestate Civili, p. 191.

23. De Indis, p. 710 . 
creati orbis, aut reparati post deluvium, maior pars hominum constituerit, ut legati ubique essent inviolabiles, ut mare esse commune, ut bello capti essent servi, et hoc ita expediret ut hospites non exigerentur, certe hoc haberet vim etiam aliis repugnantibus"24

Em uma passagem, cujo contexto infelizmente não pudemos examinar, ViTória aponta como Jus Gentium positivo, não só o que é fruto do consentimento da maioria, mas os tratados particulares entre dois povos ${ }^{25}$.

À guisa de conclusão observamos: - embora ViTóRIA fale freqüentemente em "consentimento da maioria dos povos" ou da "auctoritas totius orbis" como elementos constitutivos eficientes do Jus Gentium, nada ha que indique como isto concretamente se faz.

Sem querer e ter a preocupação de enquadrar o Mestre de Salamanca dentro de esquemas científicos de um ramo do saber que se estruturou reflexamente, ou melhor, epistemològicamente, mais tarde, diríamos que o costume seria a fonte material do Jus Gentium.

\section{Jus Gentium, defensável pela guerra.}

Que devem as repúblicas perfeitas fazer quando vêm, em seu prejuizo, violado os preceitos do Jus Gentium?

24. Ibidem. p. 710. Note-se "mare esse commune".

25. "Loquendo de illis quae sunt juris gentium legitimo modo facta id et de jure humano scripto, non est dubium quinfacere contra illud sit peccatum, quia leges, ut multo ties diximus, obligant in conscientia. Sed. dubium est an sit peccatum violare jus gentium quod nondum non est cancitum apud aliquos, id est dubium est loquendo de jure gentium non scripto, vel etiam de scripto quod non obligat omnes homines de mundo.. Duplex est jus positivum... Quoddam est jus positivum ex privato pacto et consensu, et quoddam ex pacto publico. Ita de jure dicimus, quoddam factum est ex consensu gentium et nationum". Et isto modo legati admissi sunt de jure gentium" (Comentarios In Ila IIae, qu57, a.3, n. 3) (Apud T. URDANoz, op. citatum, p. 585). 
Os povos podem individualmente nestes casos recorrer a guerra. No caso concreto das relações entre indios e espanhóis a questão chegou a preocupar de tal maneira ao Mestre de Salamanca que se viu na obrigação de dedicar uma "disputatio" sôbre o assunto. ${ }^{26}$

A leitura atenta da "relictio posterior" nos dá, todavia, a impressão de que Vitória estava mais a procura de uma oportunidade para falar da guerra em geral dentro da perspectiva teológica de então. Deixou ao leitor que fizesse a aplicação ao caso concreto da conquista.

Assim como o indivíduo pode usar a fôrça quando não tem condições para ver-se defendido pela sociedade, também os povos soberanos podem se utilizar da guerra como legitima defesa.

No caso concreto dos índios e dos espanhóis, uns e outros podem defender seus direitos de povos soberanos. Os bárbaros defendendo seu direito de propriedade das terras que possuiam, os espanhóis o de conviverem com os índios nas Américas.

Uma guerra justa de ambos os lados?

Sim, porque de um lado o povo espanhol defendia as prerrogativas que lhe dava o Direito das Gentes, e de outro os bárbaros julgando a guerra ter como fim destituí-los do legitimo domínio das terras que ocupavam..$^{27}$

\section{Elementos positivos do Jus Gentium.}

Fazemos questão de relembrar aqui o caráter monográfico do De Indis que delimitou por demais o pensamento de Vitória. Ao enumerarmos, portanto, os elementos

26. "Quia possessio et occupatio provinciarum illarum barbororum, quos indos vocant, videntur maxime jure belli posse defendi, ideo, postquam in priore relection e de titulis disputavi quos hispani possunt praetendere ad illas provincias, sive justis sive injustis, visum est de jure belli brevem disputationem habere, ut relectio superior absolutior videatur" (De Indis, relectio posterior, p. 814).

27. De Indis, p. 712. 
positivos do Jus Gentium não espere o leitor uma concatenação lógica rigida entre êles..

1. Igualdade de direitos dos povos.

$\mathrm{E}$ incontestàvelmente o elemento fundamental de tôda a contribuição de Vitória ao Direito Internacional Público.

Embora não formulada de modo explícito a igualdade é pressuposto tão evidente que sem ela ruiria por terra toda a argumentação da obra, e sem ela o trabalho perderia toda sua oportunidade histórica: - defesa do índio contra a prepotência do espanhol.

Desde que os agrupamentos sociais atinjam o estágio de "respublica perfecta", com leis, magistrados, cultos religiosos, etc., o que se consegue pelo consenso comum dos povos ou pelo Jus Gentium, colocam-se em pé de igualdade jurídica com as outras repúblicas.

Nenhuma suposta superioridade vinculada ao poder, à fôrça, à religião (ainda que considerada como única verdadeira) e à cultura pode infirmar a igualdade de direitos dos povos.

2. Direito de sociedade ou de convivência e de inter-comunicação.

Este direito se concretiza: - a) na faculdade de os homens viverem onde quizerem e em todo lugar devem ter ao menos, o mesmo tratamento que se dispensa ao hóspede e ao peregrino.

b) A terra é de todos os homens e a divisão em grupos sociais autônomos e soberanos não foi feita, e não pode ter sido feita, com a intenção de suprimir a inter-comunicação.

c) Concretiza-se também no direito do livre comércio. Para tanto é necessário que a exportação e importação, que a troca de mercadorias se faça com reciprocidade, não prevalecendo portanto o interesse do mais forte. A liberdade de comércio é tão grande, que segundo VrróRIA, os principes não podem impedir seus súditos de exercê-los. A 
única limitação que se impõe é o detrimento que possa sofrer.

3. Livre utilização do Mar, dos Portos e dos Rios.

A afirmação de VrTónia é lacônica demais para que dela tiremos conclusões mais amplas: - "Jure naturali comunia sunt omnium et aqua profuns et mare: item flumina et portus, atque naves jure gentium undecumque licet applicare"28.

4. Direito de cidadania e de oportunidade de trabalho para o estrangeiro.

Embora reconheçamos que neste particular ViróRta não tenha fixado bem os limites dos direitos, que chamamos de internacionais público e privado, o Mestre exige dos Estados respeito por vários direitos dos estrangeiros: - o direito de residir, de trabalhar, de cidadania, de não ser expulso sem causa justa.

5. Direito de defesa dos inocentes.

Independentemente de qualquer motivação religiosa um povo pode intervir para libertar os inocentes da morte. ${ }^{28}$

6. Integração dentro da soberania de outro povo.

Independentemente de qualquer razão de ordem religiosa, qualquer povo, através de uma aceitação da maioria, pode abdicar sua soberania e submeter-se a uma uutra. A única condição é que isto se faça livremente.

7. Direito de Colonização.

A simples inferioridade cultural ${ }^{30}$ não parece razão suficiente para intervir na vida de um povo, tendo como conseqüência a perda da soberania.

28. De Indis, p. 707 .

29. De Indis, p. 720 .

30. De Indis, p. 723 . 


\section{Conclusão.}

Estas são, algumas considerações sôbre a contribuição de Francisco de Vitória à ciência do Direito Internacional Público no De Indis, relectio prior.

Duas preocupações nos orientaram na confecção dêste trabalho: - rigor exegético na interpretação e completa despreocupação do enquadramento do pensamento vitoriano em uma problemática que lhe foi posterior.

Por não estar habituado, ou melhor, por não receber uma formação que o ensine a "ler" com rigor exegético as obras "clássicas" dos diversos ramos do saber, o leitor brasileiro não aprecia os trabalhos marcados por êste rigor.

Entre a leitura de uma obra em que se mostre a gênese lenta e dolorosa de um ramo do saber e outra que seja um "manual" de definições, esta é certamente a preferida.

Quantas e quantas bibliotecas públicas e privadas existem por êsse Brasil afora, em que só se encontram manuais (tenham ou não êste nome), e nem siquer uma obra dos "clássicos" dêste ou daquele ramo.

Conseqüência: - o estudioso não chega a estruturar seu pensamento, não tem condições para situar-se com espírito crítico face a avalance de escolas e correntes que se sucedem. Pessoas com êsse espírito se embasbacam fàcilmente diante de livros com citações de autores diversos quando se tratam de obras de um ecletismo sem espinha dorsal.

Tudo isso é certamente fruto de subdesenvolvimento cultural, cria círculo vicioso, mas algo é indispensável que se faça para superação.

Neste artigo há completa despreocupação de enquadramento do pensamento de VrTóRIA não só em relação a qualquer problema epistemológico do direito internacional público como ciência, como também quanto às virtuosidades latentes em relação a problema do século XX. 
Quanta coisa se poderia escrever sobre a igualdade jurídica dos povos em nossos dias?

Não há de nossa parte nenhuma objeção que isto se possa ou se deva fazer, e se não o fizermos foi por delimitação de objetivo a alcançar, condicionada sobretudo pelo fator tempo.

$\mathrm{Na}$ introdução geral que faremos à tradução do $D e$ Indis pretendemos preencher ao menos quatro das várias lacunas dêste trabalho que ora apresentamos: - situar o pensamento vitoriano em relação ao passado, de que sofreu inúmeras influências, situá--lo em relação a seus contemporâneos, diagnosticar a influência que exerceu sôbre o desenvolvimento do direito internacional público, mostrar as virtuosidades em relação a alguns problemas atuais concernentes à Sociedade dos Povos e seu direito.

\section{Fontes e Bibliografia.}

A. FONTES.

Francisco de Vitória.

1. De Indis Recenter Inventis, relectio prior.

2. De Indis, sive de jure belli hispaniorum in barbaros, relectio posterior.

3. De potestate civili.

4. De Potestate Ecclesiae prior.

5. De potestate ecclesiastica relectio secunda.

Tôdas estas obras no texto crítico editado por T. URDANOz: - Obras de Francisco de Vitoria, relecciones teologicas. Biblioteca de Autores Cristianos, Madrid, MCMLX.

B. Bibliografia.

1. Bertran DE HEREDia, Ideas del Maestro Fr. Francisco de Vitória anteriores a las Relecciones "De Indis", acerca de la colonizacion de América, segun documentos inéditos: Anuario de la Asoc. F. de Vitoria, Madrid, 1931.

2. LewIS HANKE, Colonisation et Conscience chrétienne au XVIe siècle. Traduit de l'américain par Fr. Durif. Librairie Plon, 1957. 
3. LEWIS HANKE, Cuerpo de documentos del siglo XVI sobre los derechos de España en las Indias y Filipinas, México, 1943.

4. Santiago Ramirez, El derecho de gentes, Madrid, 1955.

5. Recashans y Siches (Luiz), Las teorias politicas de F. de Vitoria, Anuario Asoc. F. de Citoria, 2 (1930).

6. Recasens y Siches (L), La filosofia del Derecho de F. do Vitória con un estudio previo sobre sus antecedentes en la patristica y la escolastica, Madrid, 1927.

7. T. URDANoz, Estudios eticos jurídicos en torno a Vitoria. Salamanca, 1947.

8. URDANOZ T., Obras de Francisco de Vitoria. Relecciones teologicas. Edicion critica del texto latino, version española, introduccion general y introducciones con el estudio de su doctrina teologico-juridica. Biblioteca de Autores Cristianos, Madrid, MCMLX.

9. Urdanoz T. Vitoria y el concepto de Derecho natural. Edicion Separata. Salamanca, 1947.

10. HoffNer Joseph, La etica española del Siglo de Oro. Cristianismo y dignidad humana. Tradução espanhola F. A. Caballero, Madrid, 1957.

11. A TRUYOL SERRA, Los principios de derecho publico en Francisco de Vitoria. Madrid, 1954.

12. A TRUYOL SERRA, Doctrina vitoriana del orden internacional. Ciência Tomista, 72 (1947), p. 123-138.

13. A TRUYol SerRa, Prémisses philosophiques et historiques du "totus orbis" de Vitoria. Anuario Ass. Francisco de Vitoria, 7 (1946-47), p. 179-201.

14. V. CARRo, La teologia y los teologos juristas ante la conquista äe America.

15. M. LASALA Llamas, Conceptos fundamentales del Derecho de gentes, segun la doctrina del $P$. Vitoria. Anuario de Ass. F. de Vitoria, I (1927-28), p. 269-305.

16. J. BRown-ScotT, The Spanish origin of International Law. F. de Vitoria and his Law of Nations. Oxford-Londres, 1934. 